\title{
ビームダウン式太陽集光装置のための機械擋䢁式顕熱蓄熱装置の開発
}

\author{
長瀬 慶紀 ${ }^{* 1}$ ，森 暢彦*2，友松 重樹 ${ }^{* 1}$ ，河村 隆介*1，金子 宏*3，松原 幸治*4
}

\section{Development of a mechanical mixing system of sensible heat storage equipment for a beam down solar concentrator}

\author{
Yoshinori NAGASE ${ }^{* 1}$, Nobuhiko MORI ${ }^{* 2}$, Shigeki TOMOMATSU*1, Ryuusuke KAWAMURA*1, \\ Hiroshi KANEKO*3 $^{* 3}$ and Koji MATSUBARA ${ }^{* 4}$ \\ ${ }^{* 1,{ }^{*} 3}$ Institute of Education and Research for Engineering, University of Miyazaki \\ 1-1 Gakuen-Kibanadai-Nishi, Miyazaki 889-2192, Japan \\ ${ }^{* 2}$ University of Miyazaki Graduate School \\ 1-1 Gakuen-Kibanadai-Nishi, Miyazaki 889-2192, Japan \\ ${ }^{* 4}$ Faculty of Engineering, Niigata University \\ 8050 Ikarashi 2-nocho, Nishi-ku, Niigata 950-2181, Japan
}

Received: 18 August 2016; Revised: 1 November 2016; Accepted: 8 December 2016

\begin{abstract}
One of the merits of a solar thermal utility is that the cost of heat storage is lower than that of an electrical battery. Furthermore, a power generation system using solar thermal energy with heat storage equipment is capable of stabilizing its output. For a parabolic trough solar concentrator, molten salt is adopted as the heat storage material using latent heat. However, molten salt is applicable only up to $600{ }^{\circ} \mathrm{C}$; this temperature is not sufficiently high for adaptation to a solar central receiver system. Therefore, we designed and produced sensible heat storage equipment for a beam down solar concentrator (a central receiver system) to offer higher temperature storage. Heat storage materials in this device are mechanically mixed, and receive the concentrated sunlight on the focal plane of the solar concentrator. First, the radiation flux distribution under CPC (Compound Parabolic Concentrator) was measured using thin film heat flux sensors to obtain the input energy for the storage equipment. Next, an experiment was carried out using the storage equipment and the beam down solar concentrator. The maximum temperature was found to reach $1070{ }^{\circ} \mathrm{C}$ at the center of the heat storage tank in this experimental conditions, and the stored energy was approximately $14 \%$ of the incident energy.
\end{abstract}

Key words : Solar concentrator, Sensible heat storage, Solar receiver, Renewable energy, Thin film heat flux sensor

\section{1. 緒言}

再生可能エネルギーの中で太陽光利用への社会的関心は高く，太陽電池ばかりでなく太陽熱を利用した発電プ ラントの建設（NEDO, 2016）や然料製造のための研究（Kodama et al., 2014）も進められている. 太陽熱利用のメ リットの一つは蓄熱であり，蓄電と比較して安価にエネルギ一を貯蔵できる。また，蓄熱装置を備えた太陽熱発 電装置は，日射の変動による発電量の変動を緩和し，さらに夜間でも発電することが可能となる.

これまでの太陽熱の蓄熱装置は，溶融塩の潜熱（Abhat, 1983）を利用したものが主流であり，溶融塩は高温に なると化学的な分解を起こすことから $600^{\circ} \mathrm{C}$ 以下の使用に限定されるため, トラフ型太陽集光装置（Morisson et al., 2008）（Michels and Pitz-Paal., 2007）で主に使用されている.タワー型太陽集光装置での蓄熱材に溶融塩を用い た研究（Hasuike et al., 2006）があるが，前述の理由からタワー型太陽集光装置のメリットである高温での蓄熱を

No.16-00370 [DOI:10.1299/transjsme.16-00370], J-STAGE Advance Publication date: 20 December, 2016

${ }^{* 1}$ 正員, 宮崎大学 工学教育研究部（厂889-2192 宮崎県宮崎市学園木花台西 1-1）

*2 宮崎大学大学院

*3 宮崎大学 工学教育研究部

${ }^{* 4}$ 正員, フェロー，新潟大学 工学部（广950-2181 新潟県新潟市西区五十嵐二の町 8050)

E-mail of corresponding author: ynagase@cc.miyazaki-u.ac.jp 
実現できていない．また，固体蓄熱材は融点近くまで温度を上昇させることができるので，溶融塩よりも高温で の蓄熱が期待できるが，低コストであるコンクリートをトラフ型太陽集光装置へ適用し $400^{\circ} \mathrm{C}$ 未満で使用してい る例（Laing et al., 2006）があるものの，タワー型太陽集光装置の特性を生かすような高温での蓄熱の研究は見当 たらない.

一方，宮崎大学にはタワー型太陽集光装置の一種であるビームダウン式太陽集熱装置（以下，BD 太陽集光装 置）が 2012 年に設置された. BD 太陽集光装置の特性を知るため，これまで BD 太陽集光装置の集光部での放射 流束計測（長瀬他, 2014, Nagase et al., 2014）やレシーバの加熱実験（Tomomatsu et al., 2015）を行ってきた. 放射 流束計測の実験では, 薄膜型熱流束計を開発し, 瞬時二次元放射流束分布を求めることができた. また，レシー バの加熱実験では, 設置したレシーバの表面温度が $1000^{\circ} \mathrm{C}$ 以上となることや温度上昇の時系列を求めることがで きた. 本研究は, それらの結果を参考にして BD 太陽集光装置に適した, また, タワー型太陽集光装置のメリッ 卜を生かした高温蓄熱装置の開発を目的とする. なお, 蓄熱材の加熱温度の目標值は, 高効率な熱機関として代 表的なガスタービンが駆動できるように $1000^{\circ} \mathrm{C}$ （Schwarzbözl et al., 2006）とする.

蓄熱装置を設計するにあたり, 太陽光が利用可能な外燃式ガスタービン（松原, 2013）の熱源として, タービ ンに供給する圧縮空気の加熱を行うことを想定した，そこで，固体蓄熱材でも粒子状であれば流動させることで 溶融塩のような使用が可能になること，あるいは，太陽光で高温にした粒子に圧縮空気を接触させ加熱すれば， 伝熱面積を大きくとれるため, コンパクトな熱交換器が実現できるものと考えた. 熱の取り出し方法は重要な問 題であるが, 本研究では, 開発した蓄熱装置によって粒子状の蓄熱材を $1000^{\circ} \mathrm{C}$ 以上に加熱することを目標とする.

\section{BD 太陽集光装置}

\section{$2 \cdot 1$ 装置および集光原理}

$\mathrm{BD}$ 太陽集光装置を図 1 に示す。この装置は, 三鷹光器（株）が開発した日本最大級のもので, 2012 年 8 月 6 日に宮崎大学に設置され，太陽熱に関する実証実験が進められている. BD 太陽集光装置の諸元を表 1 に示す.

Table1 Specifications of BD solar concentrator.

\begin{tabular}{l|l}
\hline \hline Height of tower & $16 \mathrm{~m}$ \\
\hline Number of heliostats & 88 units \\
\hline Mirror area per unit heliostat & $2 \mathrm{~m}^{2}$ \\
\hline Land area of heliostats installation & $60 \mathrm{~m} \times 60 \mathrm{~m}$ \\
\hline Solar field area & $176 \mathrm{~m}^{2}$ \\
\hline Capacity & $100 \mathrm{kWth}$ \\
\hline
\end{tabular}

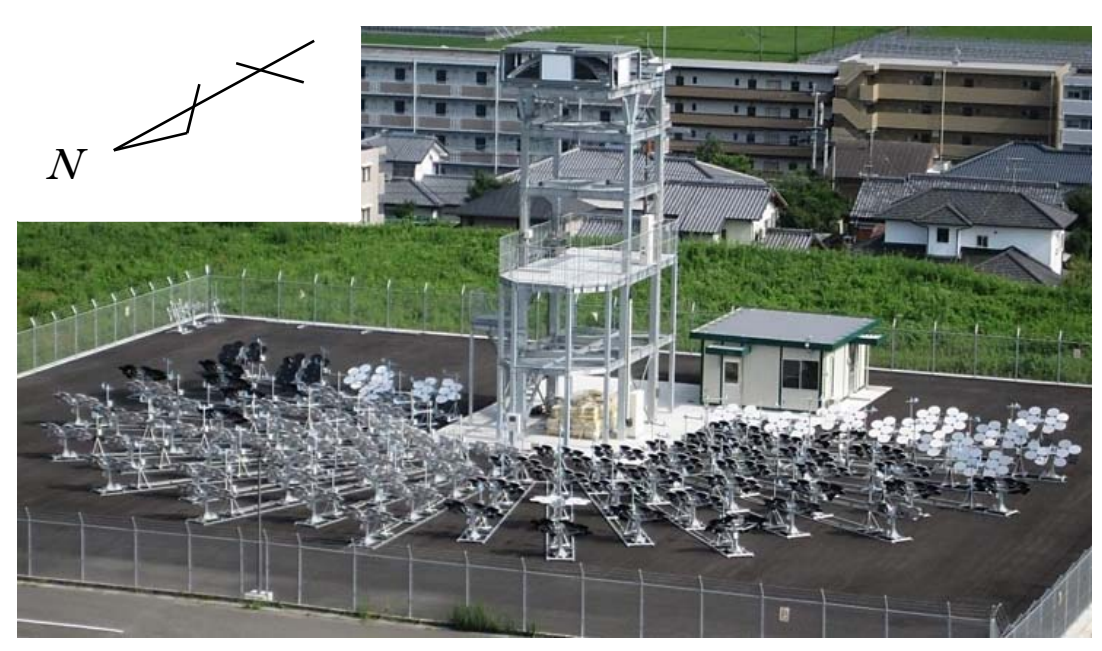

Fig.1 A BD solar concentrator developed by Mitaka Kohki Co. Ltd. was installed at University of Miyazaki in 2012. This system has a 16 - $\mathrm{m}$ tower with 88 heliostat unis over an area of $60 \mathrm{~m} \times 60 \mathrm{~m}$ on the northern side of tower. 
また， BD 太陽集光装置の集光原理を図 2 に示す。ヘリオスタットと呼ばれる 88 基の太陽追尾装置に各 10 枚 取り付けられた凹面鏡で反射された光をタワー上部の回転楕円面を持つ二次ミラー（楕円鏡）で再び反射させ， 第 2 焦点に向かって下向きに太陽光を集める方式である. 通常のタワー型太陽集光装置に比べて鏡による反射が 1 回多いため集光における損失は若干増えるが，集光部が地面に近いので，上空よりも風の影響が少なく対流に よる熱損失が低減でき，装置の設置が容易であるという特長を持つ.また，第 2 焦点に集光された太陽光をさら に約 4 倍程度濃縮するため CPC（Compound Parabolic Concentrator）（Kodama et al., 2014）が設置されており，CPC 入口は第 2 焦点に位置している.

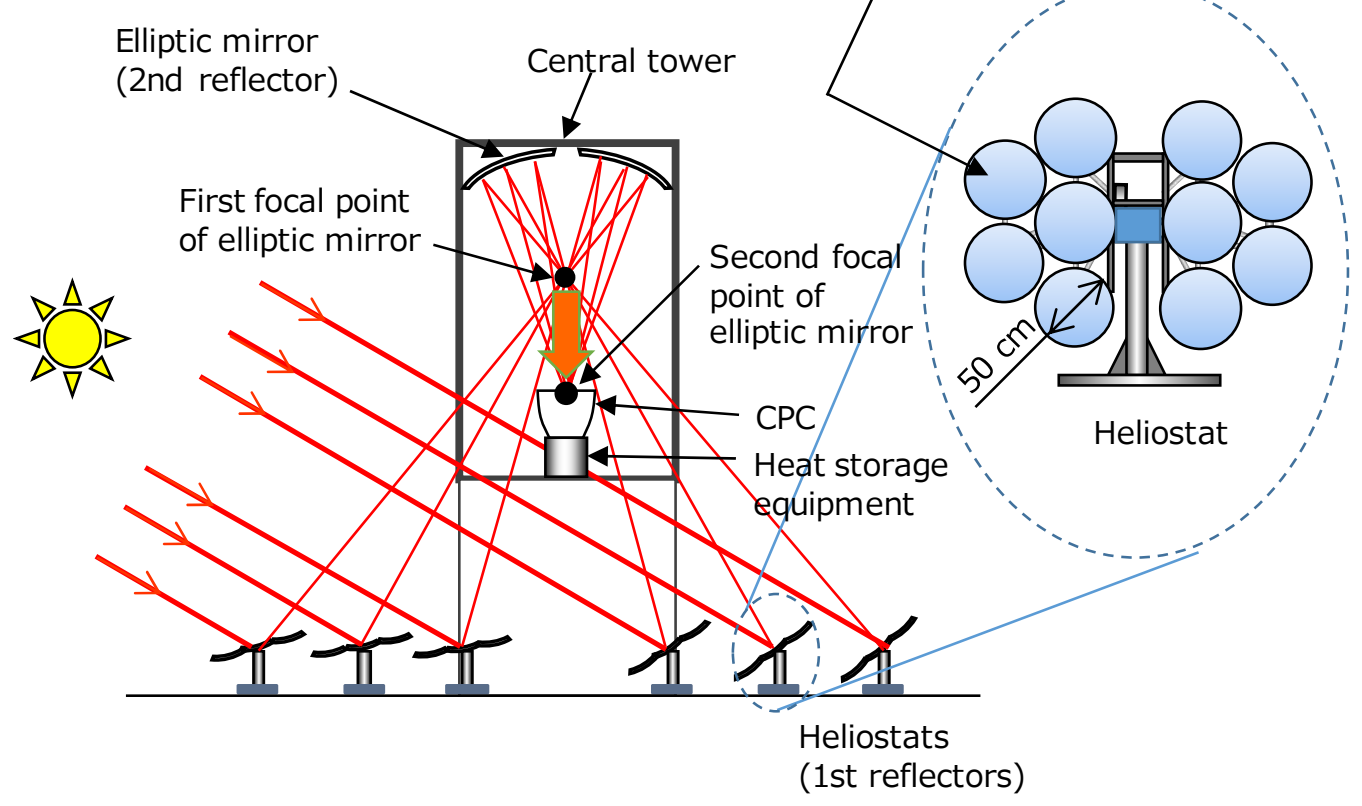

Fig.2 Principle of the BD solar concentrator. This system mainly consists of heliostats and an upper reflecting mirror (elliptic mirror). Heliostats are installed on the ground. They follow the movement of the sun and reflect sunlight onto the elliptic mirror. Reflected sunlight runs through the primary focus of the elliptic mirror, and is reflected to its secondary focus. There sunlight is concentrated by reflection, and then concentrated further using a compound parabolic concentrator (CPC) before being fed into receiver.

\section{$2 \cdot 2$ C P C 出口での放射流束分布}

CPC 出口での放射流束分布を計測するため，図 3 に示寸薄膜型熱流束計（長瀬，友松，2010）を用いた．薄膜 型熱流束計は， $\phi 3.2 \mathrm{~mm} \times 10 \mathrm{~mm}$ のコンスタンタン母材に $\phi 0.65 \mathrm{~mm}$ の銅線を貫通させ，母材表面において膜厚 $10 \mu \mathrm{m}$ の銅めっきにより母材と銅線を導通させたものである. これにより，50 $\mu \mathrm{s}$ のサンプリング間隔で母材表面 の温度変化を捉えることが可能である.

薄膜型熱流束計表面に集光された太陽光を当て, その強度を変化させると, 表面の温度変化を検知する. 得ら れた温度変化を調和解析し, 銅薄膜の吸収率で除することにより集光された太陽光の放射流束の変化を求めるこ とができる. なお，吸収率については，薄膜型熱流束計ごとに計測（長瀬他，2013）を行った.

図 4 に示寸トラバース装置に, 図 3 の薄膜型熱流束計 9 本を $50 \mathrm{~mm}$ 間隔でアームに取り付け, 角速度 $4.19 \mathrm{rad} / \mathrm{s}$ で回転軸を中心に，タイミングベルトを介してステッピングモータによりアームを回転させることで，集光部内 で薄膜型熱流束計が移動した軌跡に沿った放射流束が計測される. 薄膜型熱流束計が集光部内を通過する時間は $0.5 \mathrm{~s}$ 未満であり，この間の太陽光放射強度変化は無視できるため，この装置により，CPC 集光部の任意の断面の 二次元瞬時放射流束分布が求められる.

$\mathrm{CPC}$ 出口中心を原点にとったとき, 高さ $z=-150 \mathrm{~mm}$ （負数は CPC 出口より下方を示す）における水平 面上の二次元放射流束分布を図 5 に, 実験条件を表 2 に示す. なお, $x$ 軸は東西方向で, $y$ 軸は南北方向で あり，両軸の正方向はそれぞれ東，北を示寸．また， $x y$ 平面上に $100 \mathrm{~kW} / \mathrm{m}^{2}$ 間隔で等流束線を示してい 
る. 図 5 より放射流束の最大值は約 $300 \mathrm{~kW} / \mathrm{m}^{2}$ でその位置は CPC 中心軸より約 $20 \mathrm{~mm}$ 程度東にあるが，最 大值を中心にほぼ軸対称な分布となっている.

Table2 Experimental condition of flux measurement at the height position $\mathrm{z}=-150 \mathrm{~mm}$.

\begin{tabular}{l|l}
\hline \hline Date and time & Dec/25/2015,10:44am \\
\hline Solar direct normal incidence $(D N I)$ & $733 \mathrm{~W} / \mathrm{m}^{2}$ \\
\hline Number of heliostats $(N)$ & $74 \mathrm{units}$ \\
\hline Swing arm rotating speed & $4.19 \mathrm{rad} / \mathrm{s}$ \\
\hline Data acquisition interval & $50 \mu \mathrm{s}$ \\
\hline Electric wave filter & $1 \mathrm{kHz}$ (low pass) \\
\hline
\end{tabular}

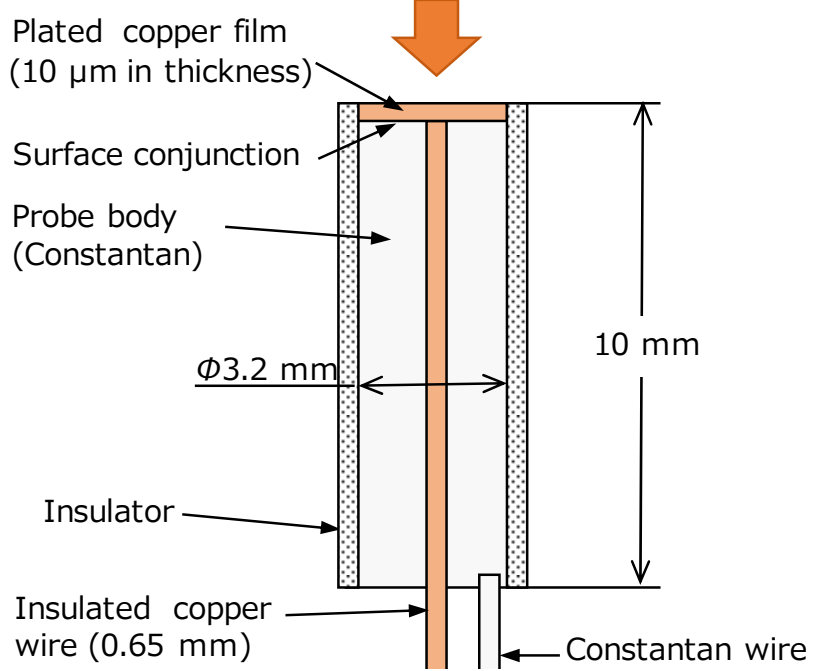

Fig.3 Structure of thin film heat flux sensor. A constantan rod and an insulated copper wire are connected by a copper plate (thickness: $10 \mu \mathrm{m}$ ). They comprise a thermocouple on upper surface of constantan rod. This sensor can be used to capture the surface temperature change at a sampling interval of $50 \mu \mathrm{s}$. The radiation flux is obtained from harmonic analysis of temperature change and by dividing absorption rate of copper film.

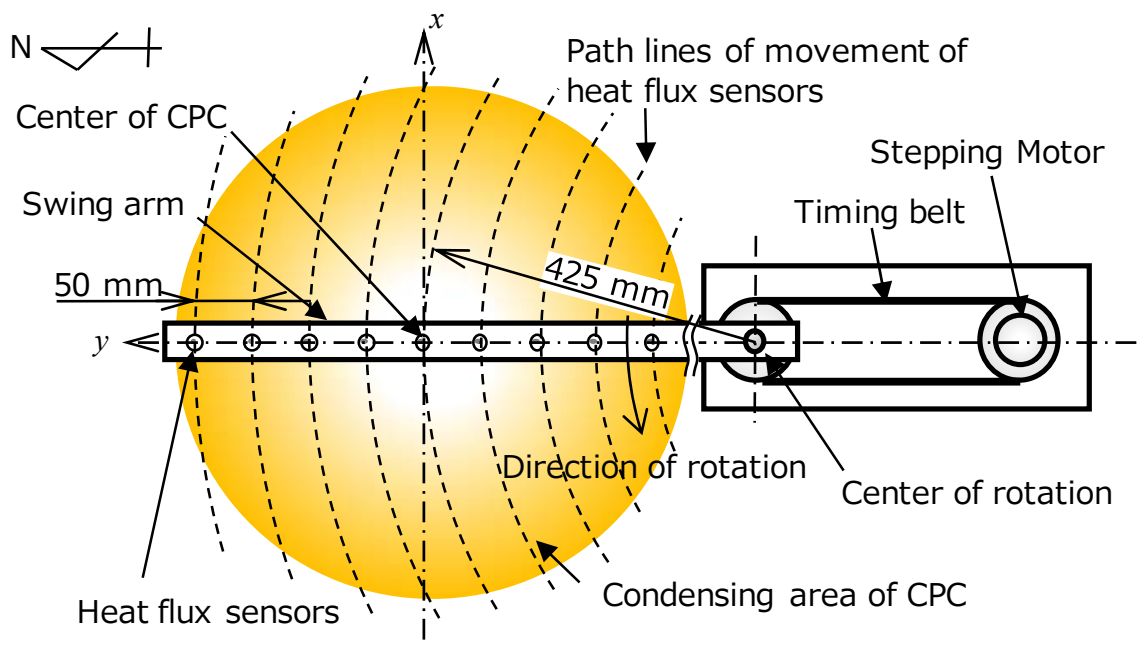

Fig.4 The traverse equipment for heat flux sensors. Nine heat flux sensors are attached to the arm every $50 \mathrm{~mm}$. The sensors are moved together over condensing spot of sunlight by the revolution of arm. The arm performs revolutions using stepping motor. Then, radiation fluxes on path lines of heat flux sensors are obtained. 


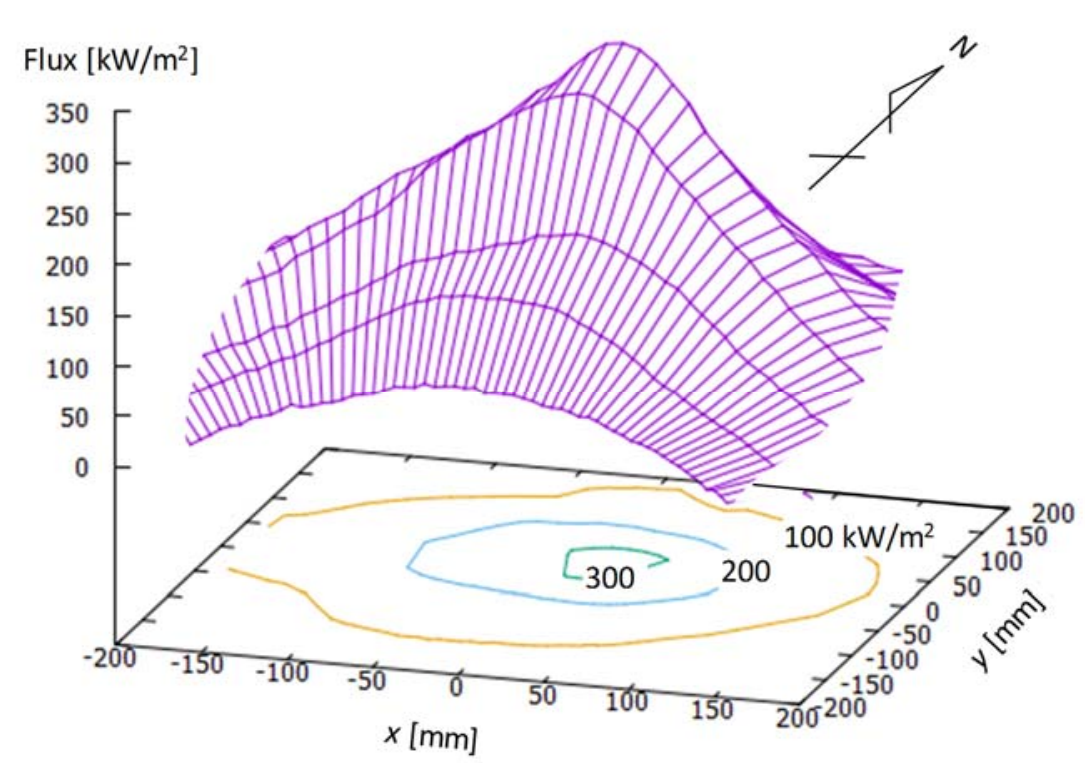

Fig.5 Experimental result of flux measurement over the condensing area of CPC at $\mathrm{z}=-150 \mathrm{~mm}$. On the $\mathrm{x}-\mathrm{y}$ plane, contour lines are shown at an interval of $100 \mathrm{~kW} / \mathrm{m}^{2}$. The maximum value of radiation flux is approximately 300 $\mathrm{kW} / \mathrm{m}^{2}$. Although its position is to the east (approximately $20 \mathrm{~mm}$ ) the CPC center, its shape is axially symmetric about the maximum value.

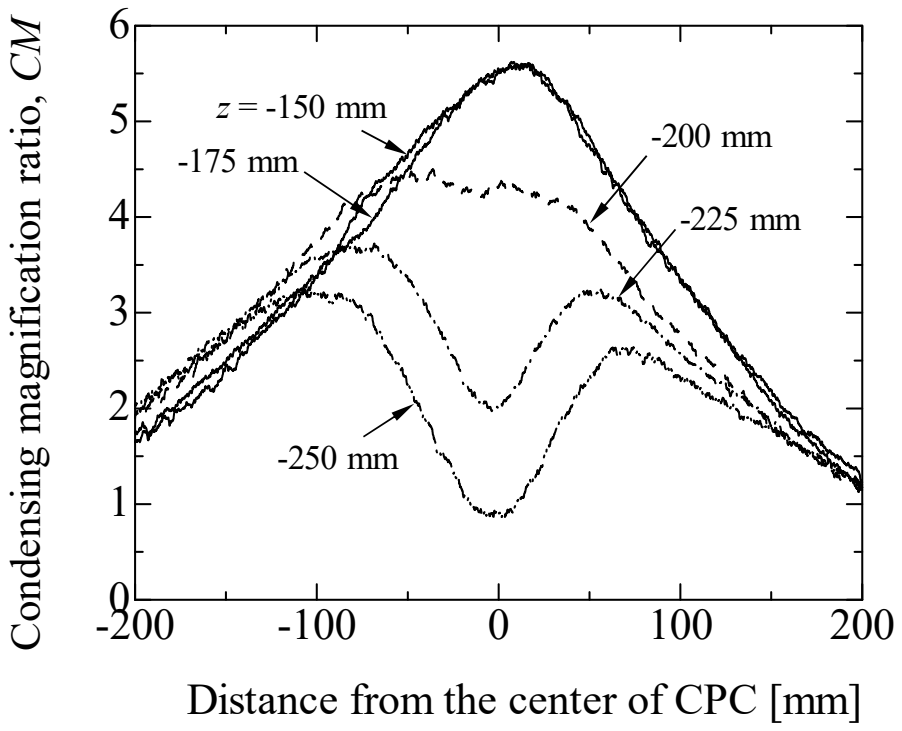

Fig.6 $C M$ distribution at each value of $z$ using heat flux sensor passing through the center of CPC. Radiative flux distributions on horizontal plane at heights of $z=-150 \mathrm{~mm}$ and $\mathrm{z}=-175 \mathrm{~mm}$ approximately have the same values and shapes. However, in accordance with heights below $\mathrm{z}=-200 \mathrm{~mm}$, their values become lower and the shapes of their centers become concave.

次に， CPC下の高さごとの放射流束分布を求めた．なお，高さ位置を変えるごとに，直達日射量およびへリオ スタットの基数が変化するため, 式(1)に示すように薄膜型熱流束計によって求めた放射流束 $R F$ を直達日射量 $D N I$ およびヘリオスタットの基数 $N$ で除した，へリオスタット 1 基あたりの面積平均集光倍率 $C M$ を導入した.

$$
C M=\frac{R F}{D N I \cdot N}
$$

図 6 は， $z=-150 〜-250 \mathrm{~mm}$ の区間で高さを $25 \mathrm{~mm}$ ずつ変えて水平面上の放射流束を計測し，ほぼ $x$ 軸に沿つ て移動すると考えられる回転軸から $425 \mathrm{~mm}$ に設置された CPC 中心軸を通る薄膜型熱流束計で計測した放射流束 から求めた $C M$ を縦軸に, 熱流束計の中心からの距離を横軸にとったものである.ただし, 横軸の正方向は図 5 
における $x$ 軸の正方向である，また，実験日，トラバースの角速度およびデータ収録の条件は表 2 と同じで，そ れ以外の計測条件を表 3 に示す. 図 6 より, $z=-150 \mathrm{~mm}$ および $z=-175 \mathrm{~mm}$ の高さの水平面上の放射流束分布は, $\mathrm{CPC}$ 中心部が高く周辺にいくに従って低くなっており絶対值もほぼ等しい. しかし，CPC の集光中心部は，下に いくほど CPC 内の鏡で反射された光が当たらなくなり, 2 次ミラーからの反射光が広がりながら直接到達するた め, 高さ位置 $(z)$ が低くなるに従って, 中心部がくぼんだ形状が顕著となる.

Table 3 Experimental conditions of flux measurements with varying positon of $z$.

\begin{tabular}{c|c|c|c}
\hline \hline$z[\mathrm{~mm}]$ & Time & $D N I\left[\mathrm{~W} / \mathrm{m}^{2}\right]$ & $N$ \\
\hline-150 & $10: 44$ & 733 & 74 \\
\hline-175 & $11: 20$ & 774 & 77 \\
\hline-200 & $12: 41$ & 750 & 80 \\
\hline-225 & $13: 00$ & 780 & 74 \\
\hline-250 & $13: 21$ & 799 & 71 \\
\hline
\end{tabular}

\section{3. 機械擋拌式顕熱蓄熱装置}

\section{1 動作原理および特長}

図 7 に本研究で設計・製作した機械摚拌式顕熱蓄熱装置の概略図を示す. BD 太陽集光装置の集光方向を考慮 し，また，高温蓄熱を実現するため，図７のように固体蓄熱材上面を集光された太陽光で直接加熱する形式のレ シーバの機能を備えた蓄熱装置とした.

蓄熱槽は，内外のシリンダ，面積が互いに等しい内側円形ピストンと外側ドーナツ形ピストン，外気との対流 熱伝達を防止するための透過率 $\sigma=0.9$ の石英ガラスで囲まれた空間でその中に蓄熱材がある. 両ピストンは同 じ速さで互いに逆方向になるように上下方向（ $z$ 軸方向）に移動することで, 蓄熱材は摚拌され, 蓄熱材を構成す る蓄熱粒子は表面で順に加熱される仕組みである。

蓄熱粒子は，融点が $2072^{\circ} \mathrm{C}$ （国立天文台編，2015）と高く, 種々の粒径のものを入手しやすいアルミナ球を用 いた. また，粒径については，粒子中心部まで速く加熱されるためできるだけ小さいものが良いが，ピストンと シリンダのすきまを考慮して $\phi 5 \mathrm{~mm}$ とした。
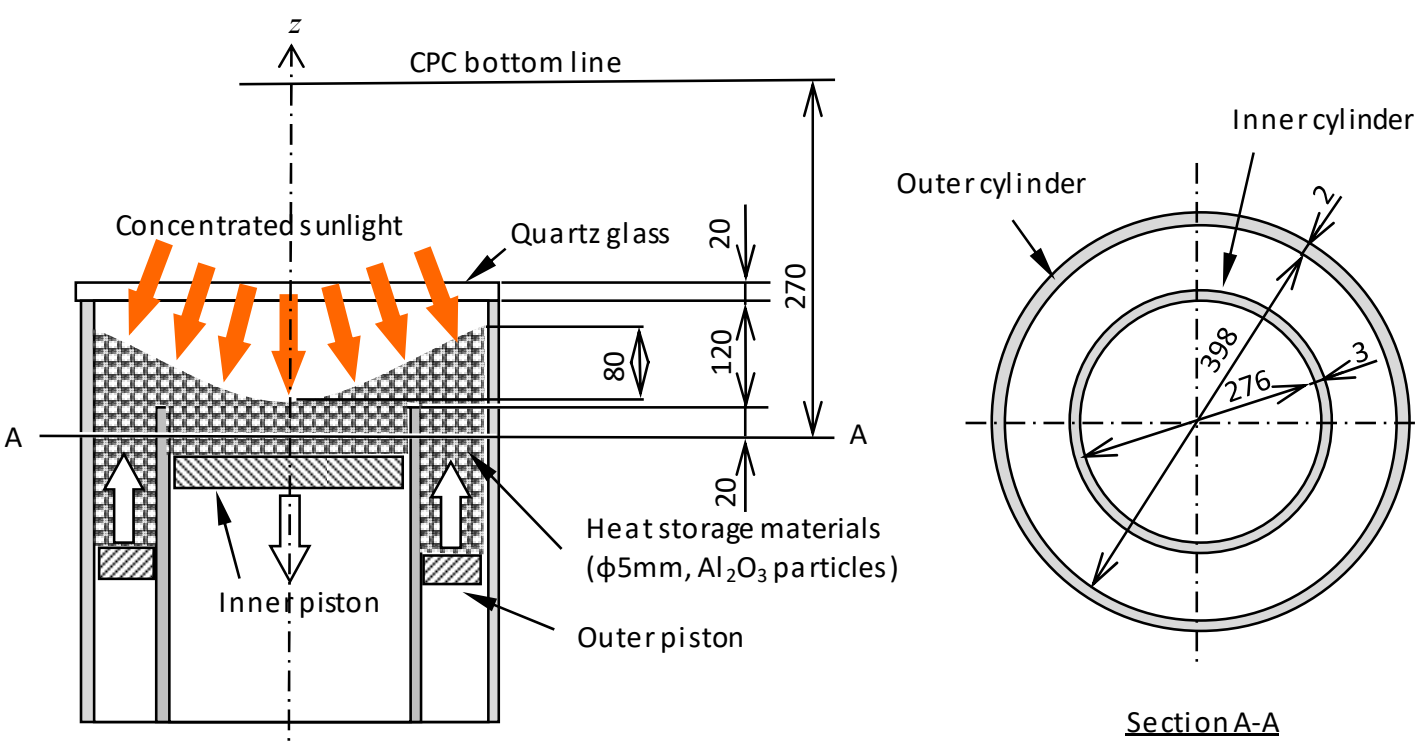

\section{$\underline{\text { Section A-A }}$}

Fig.7 Cross section of heat storage tank. The storage tank comprises an internal and an external cylinder, an inner circular piston, an outer donut type piston and a quartz glass that prevents convection heat transfer between external air and particles. Both pistons move on the $\mathrm{z}$ axis at same speed, but in inverse directions. Particles are heated in turns at the surface of medium. 
この蓄熱装置には次のような特長を持つ.

（1）固体蓄熱材に顕熱で蓄熱を行うため，溶融塩による潜熱蓄熱よりも高温での蓄熱が可能である.

（2）蓄熱材を直接太陽光で加熱するため，間接加熱方式より蓄熱材を加熱する際の熱損失が少ない.

（3）ピストンの移動速度を変更することにより，蓄熱材の加熱温度を容易に制御できる。また，入射強度に合わ せてピストン速度を制御することで，蓄熱材温度を設定温度に保つことが可能となる。

Table 4 The coordinates of the measuring points of thermocouples in figure 8 . Where, "|r|" means distance from the center of the storage tank.

\begin{tabular}{|c|c|c|c|c|c|c|c|}
\hline Symbol & $x[\mathrm{~mm}]$ & $y[\mathrm{~mm}]$ & $|r|[\mathrm{mm}]$ & Symbol & $x[\mathrm{~mm}]$ & $y[\mathrm{~mm}]$ & $|r|[\mathrm{mm}]$ \\
\hline (1) & 0 & 0 & 0 & (9) & 0 & 100 & 100 \\
\hline (2) & -35 & -35 & 50 & (10) & 0 & -170 & 170 \\
\hline (3) & 71 & -71 & 100 & (11) & 0 & 170 & 170 \\
\hline (4) & 106 & 106 & 150 & (12) & 25 & 0 & 25 \\
\hline (5) & 0 & 0 & 0 & (13) & 50 & 0 & 50 \\
\hline (6) & 0 & -50 & 50 & (14) & 100 & 0 & 100 \\
\hline (7) & 0 & 50 & 50 & (15) & -151 & 0 & 151 \\
\hline (8) & 0 & -100 & 100 & (16) & 189 & 0 & 189 \\
\hline
\end{tabular}

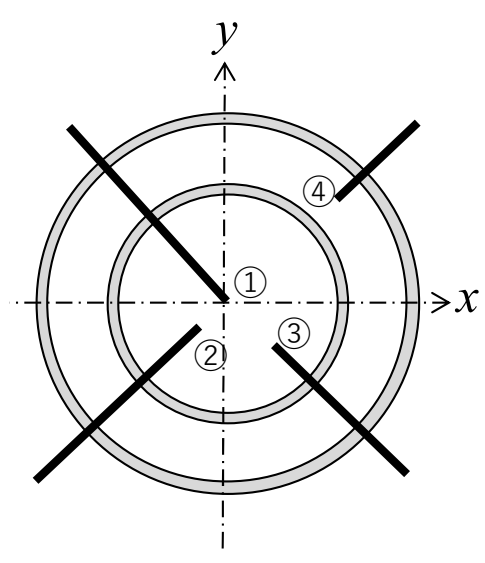

(a) Thermocouples set at cylinders

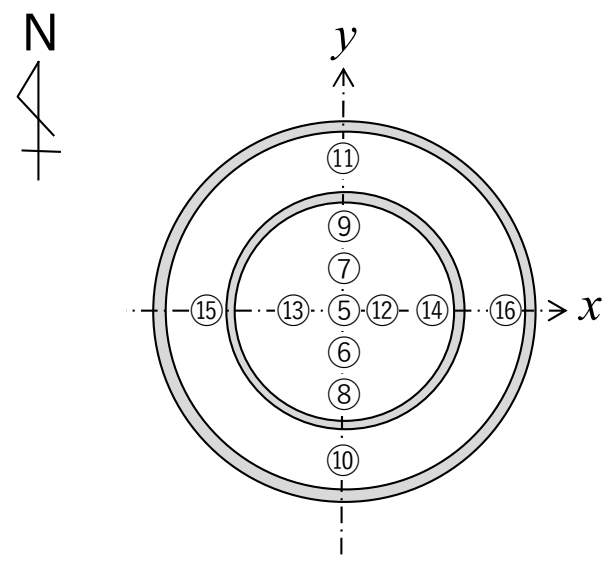

(b) Thermocouples set at pistons

Fig.8 Locations of thermocouples set in the storage tank. Figure 8(a) shows the mounting positions of thermocouples (1) (4)). To perform measurements of fixed points, the height position is set on AA cross section in Figure 7. Figure 8(b) shows the mounting positions of thermocouples (5)-(16), which move with the piston. The height positions are $20 \mathrm{~mm}$ above the piston-top surfaces.

\section{2 ピストンの移動方向と蓄熱槽内の温度計測位置}

ピストンの動く方向により，加熱面の形状が変化するが，次のような理由から，図 7 に示すように内側ピスト ンが下降する方向で実験を行った.

(1) 集光された太陽光は CPC 中心から外側に広がるため, 蓄熱材の外周部における $z$ 方向の位置が高くなること で，蓄熱材に照射されず蓄熱槽側壁にもれる太陽光が減少し，入射損失が低減する.

(2) 蓄熱材表面の形状が下に凸の形となり, 図 6 より入射強度が均一に近づき蓄熱材内部の温度分布がより小さ くなる.

（3）加熱終了後に蓄熱粒子が内部円筒に集まり，外部円筒が空気の断熱層となるため保温効果が高まる.

蓄熱槽には，蓄熱材加熱面の形状を考慮して 16 本の熱電対を取り付け，温度計測を行った。温度計には $\mathrm{K}$ 型 シース管熱電対を使用し，その取り付け位置(1)〜16)を図 8 に，温度計測位置である熱電対先端の座標を表 4 に示 す.なお，図 8(a)はシリンダに固定され定点計測を行う熱電対(1)〜 (4)の取り付け位置を示し，高さ位置は図 7 の 
AA 断面上にある. 図 8(b)はピストンとともに移動する熱電対(5)〜(16)の取り付け位置で, 高さ位置はピストン上 面から $20 \mathrm{~mm}$ 上方である.

\section{BD太陽集熱装置による蓄熱槽加熱実験}

\section{1 実験条件}

BD 太陽集光装置での蓄熱槽の加熱実験において，まず，アルミナ球と空気の混合材料としての蓄熱材料の断 熱効果を検討するために 30 分間ピストンを停止し, CPC で集光された太陽光を照射した. 蓄熱材は, ピストン が静止している実験開始から 30 分間, 表面が平らな状態で $z=-210 \mathrm{~mm}$ の高さ位置にある. 次に, 蓄熱材料の 温度を定常的に $1000 \mathrm{~K}$ 上昇させるため, 式(2)より, 開始 30 分後, $t=23$ 分間かけてピストンを $\mathrm{z}$ 方向に $160 \mathrm{~mm}$ 等速運動させ，太陽光を照射した。

$$
t=\frac{m \cdot c \cdot \Delta T}{C M \cdot \sigma \cdot \varepsilon \cdot N \cdot A \cdot 60}
$$

ただし, 粒子の質量, 比熱, 吸収率をそれぞれ $m=20 \mathrm{~kg}, c=1.2 \mathrm{~kJ} /(\mathrm{kg} \cdot \mathrm{K}), \varepsilon=0.6$, ガラス単体の透過率 $\sigma=$ 0.9 , ヘリオスタット 1 台あたりの面積平均集光倍率 $C M=3$, ヘリオスタットの集光基数 $N=88$, 直達日射量 $q$ $=1000 \mathrm{~W} / \mathrm{m}^{2}$, 集光面積 $A=0.126 \mathrm{~m}^{2}$ とする. 実験条件は表 5 のとおりである. さらに, 蓄熱材が平らな状態から ピストンを駆動させたときの表面形状の変化を図 9 に示す. 図 9 より蓄熱材の表面形状は，2 分経過するとすり 鉢状の定常な状態となることがわかる.

\section{2 BD 太陽集光装置で加熱実験結果および考察}

図 10 に蓄熱槽に取り付けた熱電対の温度経過を示す，図 10(a)はシリンダに固定した熱電対による定点計測の 結果で, 図 10(b)は内側ピストンとともに移動する熱電対によるものであり, 図 10(c)は外側ピストンとともに移 動する熱電対による計測結果である. また, 図 10(a)の一点鎖線は直達日射量 (DNI) を示す. 図 10(a)より DNI の変動は小さく, ピストン停止時で 942 $963 \mathrm{~kW} / \mathrm{m}^{2}$, ピストン駆動時で $953 \sim 969 \mathrm{~kW} / \mathrm{m}^{2}$ で実験中ほぼ一定であ るとみなすことができる．また，ピストンが停止している 30 分までは，熱電対(1)〜(4)で計測した結果から，中 心部に近づくほど温度が高くなることがわかる．これは，初期状態での蓄熱材表面は，CPC 出口から $z=-210$ mm の高さにあるので, 図 9 から放射流束が中心に向かうにつれて大きくなるためである.

Table 5 Experimental conditions of heat storage using BD solar concentrator.

\begin{tabular}{l|c}
\hline \hline Date and start time & Jan $/ 20 / 2016,12: 00$ \\
\hline Average $D N I$ when pistons stop $\left(D N I_{a v r, s}\right)$ & $953 \mathrm{~W} / \mathrm{m}^{2}$ \\
\hline Average $D N I$ while pistons moving $\left(D N I_{a v r, m}\right)$ & $962 \mathrm{~W} / \mathrm{m}^{2}$ \\
\hline Number of heliostats $(N)$ & $79 \mathrm{units}$ \\
\hline Piston speed & $0.116 \mathrm{~mm} / \mathrm{s}$ \\
\hline Data acquisition interval & $1 \mathrm{~s}$ \\
\hline
\end{tabular}

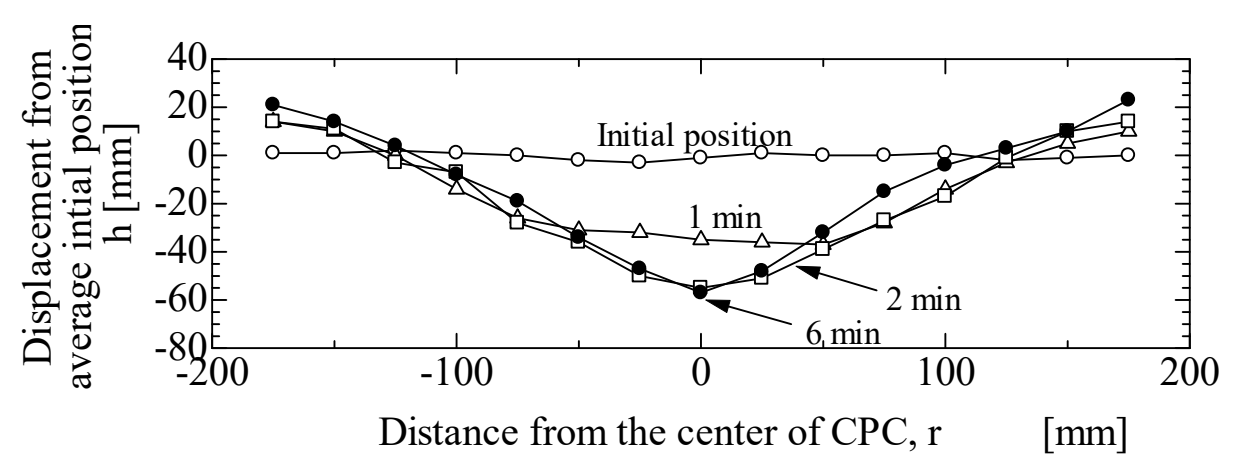

Fig. 9 Time sequence of the shape change of the surface of the storage material. After two minutes from initial position, the surface shape of the heat storage material becomes a conical steady state. 


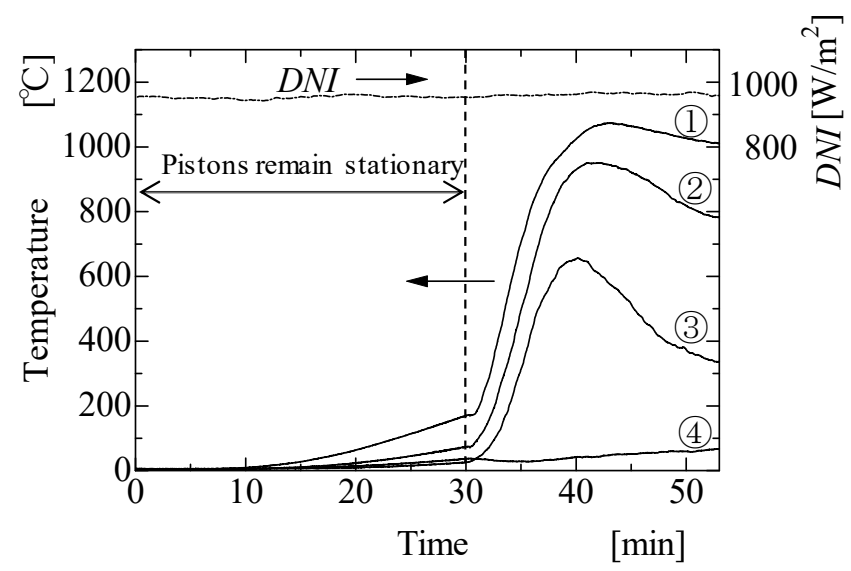

(a) Sequence of temperature changes obtained from thermocouples set at cylinders and DNI

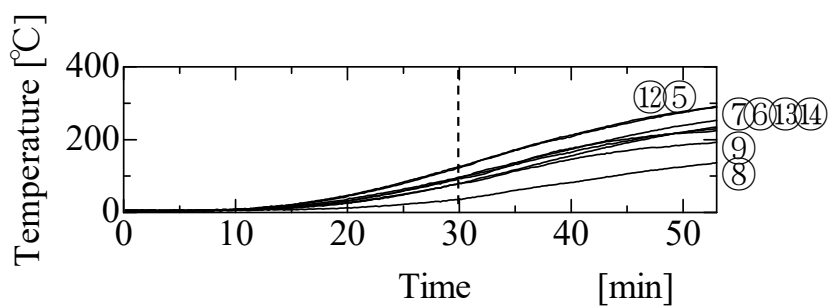

(b) Sequence of temperature changes obtained from thermocouples set at inner piston

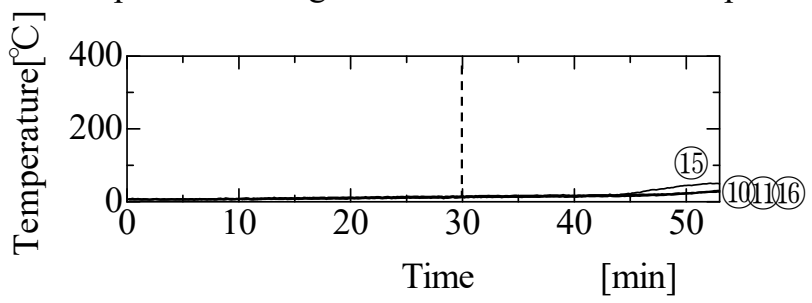

(c) Sequence of temperature changes obtained from thermocouples set at outer piston

Fig.10 Time sequences of temperature changes obtained from thermocouples. The heat storage materials can be heated up to $1070{ }^{\circ} \mathrm{C}$ using this receiver. Bases on the temperature changes while the piston is in the stationary state for up to $30 \mathrm{~min}$, the amount of heat transfer by thermal conduction in the thermal storage material is found to be small. From the temperature changes at the time of pistons movement, it can be observed that temperature changes are caused by irradiation of sunlight.

ピストンが移動を開始してからは，実験開始後 30〜40 分で静止状態のとき表面および表面付近にあった蓄熱 粒子が移動して熱電対に触れるため温度が急激に上昇し, 実験開始後 40 分で最高温度 $1070^{\circ} \mathrm{C}$ となるが, 蓄熱材 表面にあった蓄熱粒子への入射量が一定值になるため, 温度が下降しはじめる. さらに, 実験開始後 30 分までの ピストン静止状態から，この蓄熱材内での熱伝導による伝熱量は小さいことが，また，ピストン移動時での温度 変化から, 主として太陽光による直接加熱によって温度変化が生じていることがわかる，これは，蓄熱粒子どう しは点で接触するため伝熱面積が小さいことと, 蓄熱粒子に挟まれた空気は $0.1 \mathrm{MPa}, 1000^{\circ} \mathrm{C}$ で熱伝導率が 0.08162 $\mathrm{W} /(\mathrm{m} \cdot \mathrm{K})$ （日本機械学会，2009）と低いためである.

図 10(b)より，熱電対(5)については，図 10(a)の熱電対(1) と実験開始後 30 分まではほぼ同じ位置にあるため，同 様の温度経過を示しているが，その後，温度上昇割合は緩やかになる．これは上層の蓄熱粒子からの熱伝導によ る伝熱量が減少していくためである. また，内側ピストンに取り付けられた熱電対は中心に向かうにつれて同時 刻における温度は高くなるが, 熱電対(5) と同様の温度経過を示寸。一方, 図 10(c)外側ピストンでは, 蓄熱材表面 には次々に温度が低い蓄熱粒子が供給されるため, 内側シリンダの表面の温度よりも低いことから図 10(b)に比 べて熱伝導による熱移動量がさらに小さいため温度の上昇が小さい.

また，ピストンを静止させた時間 $t_{s}$ と移動させた時間 $t_{m}$ をあわせた時間内に蓄熱槽に入射されたエネルギー $Q_{i n}$ は, 式(3)より求まる. 


$$
Q_{\text {in }}=\left(C M_{a v r, s} \cdot D N I_{a v r, s} \cdot t_{s}+C M_{a v r, m} \cdot D N I_{a v r, m} \cdot t_{m}\right) \cdot \sigma \cdot N \cdot A
$$

ここで，CM $M_{a v r s}$ および $C M_{a v r m}$ は，ピストンが静止しているときと移動しているときのそれぞれのへリオスタッ 卜 1 基あたりの面積平均集光倍率である. ピストンが静止した状態では，蓄熱材の表面位置が $z=-210 \mathrm{~mm}$ なの で, 図 6 において $z=-200 \mathrm{~mm}$ と $z=-225 \mathrm{~mm}$ のそれぞれの $C M$ の面積平均を求め内挿して $C M_{a v r, s}=2.9$ が得られ, ピストン移動時は，外側シリンダ付近では高さ位置が $z=-180 \mathrm{~mm}$ であるため $z=-175 \mathrm{~mm}$ と $z=-200 \mathrm{~mm}$ での $C M$ の面積平均をもとに $C M_{a v r, m}=3.0$ が得られた。 また， $D N I_{a v r, s}$ および $D N I_{a v r, m}$ は，表 5 に示すとおりピストン静止時 と移動時それぞれの時間平均直達日射で, 石英ガラス単体の透過率 $\sigma=0.9$, 集光に関与したヘリオスタットの基 数 $N=79$ および断面積 $A=0.126 \mathrm{~m}^{2}$ を式(3)に代入した結果, $Q_{i n}=80 \mathrm{MJ}$ となった.

一方，蓄熱槽内に蓄熱された概略の熱量を計算するにあたり，蓄熱槽内の温度分布を次のようにして求めた. すなわち，図 10 におけるピストン移動時すなわち実験開始後 30〜 53 分の期間において，定点計測のための熱電 対(1)〜(4)から得られた温度の時系列をもとに，蓄熱粒子は内側シリンダ内にある熱電対(1)〜(3)に接触した後も温 度が変化しないまま移動するものとして，すなわち 30～53 分のときの温度を蓄熱槽内の $z=-430 \sim-270 \mathrm{~mm}$ の 位置での温度とみなして内部の温度分布を予測した. 図 11 は, 熱電対で計測していない位置の温度を直線補間し

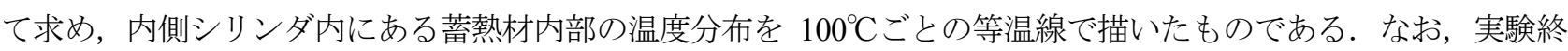
了直前では蓄熱材の加熱状態は定常状態に達しているものと考え，シリンダに固定された熱電対の取り付け位置 $z=-270 \mathrm{~mm}$ より上は, 実験終了時の温度すなわち $z=-270 \mathrm{~mm}$ の温度に等しいとした.

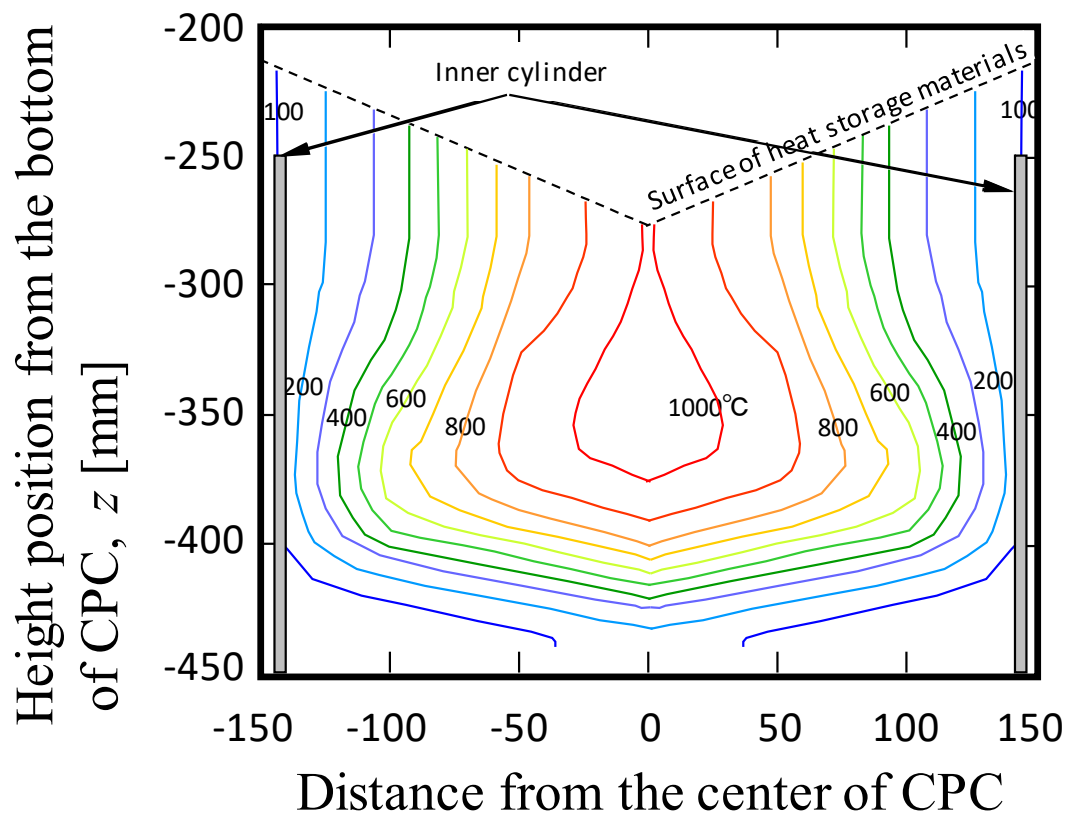

Fig.11 The calculated result of temperature distribution in storage tank obtained from Figure10. From this temperature distribution, the amount of heat stored in the tank was found to be $44 \mathrm{MJ}$, which is $59 \%$ of incident energy.

また，外側と内側のシリンダの間にある蓄熱材は，予熱を目的として加熱されているため，実験終了後にこの 区間に存在する蓄熱材が顕熱として蓄熱する熱量を蓄熱量から除外することとした. よって，内側シリンダ内の 蓄熱材のみを考慮して，蓄熱量を求めると $11 \mathrm{MJ}$ となり，入射エネルギ一の約 $14 \%$ \%が蓄熱されたことがわかっ た．ただし，嵩密度は質量と体積の測定により求め $2100 \mathrm{~kg} / \mathrm{m}^{3}$ である。また，アルミナの任意の温度における比

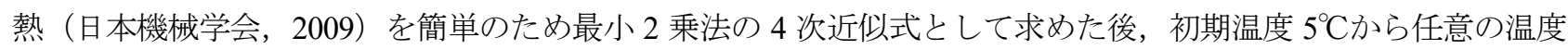

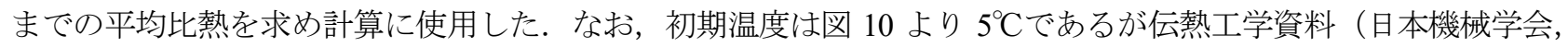
2009）からは $27^{\circ} \mathrm{C}$ 未満のアルミナの比熱は不明であり蓄熱量は微小であるため，全体の蓄熱量には影響を与えな いものと考え, 図 11 における $27^{\circ} \mathrm{C}$ 未満の蓄熱粒子の蓄熱量は無視した.

キルヒホッフの法則から吸収率は放射率と等しいとして，アルミナ（研磨面）の全半球放射率をもとに吸収率 を予測すると，アルミナの $700^{\circ} \mathrm{C}$ 超える高温での吸収率は不明であるが， $700^{\circ} \mathrm{Cで}$ 吸収率が約 0.6 であり，300 $\mathrm{C}$ 
から $700^{\circ} \mathrm{C}$ までは温度が上昇するにつれて吸収率は低下寸る（日本機械学会, 2009). 吸収されなかった光は, 石 英ガラスから外部および側壁に反射したものと考えられることから，さらに入射エネルギーに対する蓄熱割合を 高めるためには, 高温でも吸収率が高い蓄熱材を採用することが必要と考えられる，なお，蓄熱材表面形状を下 に凸状にしたことは，蓄熱材表面からの反射光を石英ガラスから外部に出さないことに貢献しているものと考え られる．また，蓄熱槽上部は石英ガラスの周辺に $20 \mathrm{~mm}$ 程度の隙間があり，下部も気密性が低いため，対流によ る熱損失が無視できないことから, 蓄熱槽の密閉性を高める必要がある.

データの信頼性を高めるため複数回の実験が必要ではあるが，以上の結果から，本研究で開発した蓄熱装置が $1000^{\circ} \mathrm{C}$ 以上の顕熱蓄熱を実現可能であることは示寸ことができた. なお, 蓄熱温度や蓄熱量は, 入射エネルギー, 粒子の吸収率や比熱等の物性值, 蓄熱装置のピストンの移動速度などに依存するため, 今後, これらとの関係を 検討する必要がある.

\section{5. 結言}

$\mathrm{BD}$ 太陽集光装置のための蓄熱装置を設計・製作した。この蓄熱装置は, 蓄熱材に直接太陽光を照射し, 機械 的に蓄熱材を摚拌し, 顕熱による蓄熱を行うものである. BD 太陽集光装置での集光実験を行った結果, 次の結 論を得た.

(1) 蓄熱材を構成する蓄熱粒子に $\phi 5 \mathrm{~mm}$ のアルミナ球を用い, ピストンを 30 分停止した後 23 分間等速で $160 \mathrm{~mm}$ 移動させて太陽光を照射した．今回の実験条件では，蓄熱材の中心部で最高温度が $1070^{\circ} \mathrm{C}$ なった.

（2）蓄熱材内部は, 熱伝導による伝熱量は小さく, 主として太陽光による直接加熱によって温度変化が生じてい ることがわかった。

（3）今回の実験条件では，太陽光の入射エネルギーの約 $14 \%$ が蓄熱材に顕熱として蓄熱されたことがわかった.

\section{謝 辞}

本研究は, JSPS 科研費 16K06973 の助成を受けたものである. また, BD 太陽集光装置での実験に協力いただ いた宮崎大学技術職員の木村正寿氏，三宅玩磨氏，濱畑貴之氏，ならびに放射流束計測に協力いただいた川崎重 工業（株）の菊永拓馬氏と太平電業（株）の久堀友嗣氏に記して謝意を表す.

\section{文献}

Abhat, A., Low temperature latent heat thermal energy storage: Heat storage materials, Solar Energy, Vol.30, No.4(1983), pp.313-332.

Hasuike, H., Yoshizawa, Y., Suzuki, A. and Tamaura, Y., Study on design of molten salt solar receivers for beam-down solar concentrator, Solar Energy 80(2006), pp.1255-1262.

日本機械学会, 伝熱工学資料改訂第 5 版(2009), p.162, p.287, p.296.

Kodama, T., Gokon, N., Matsubara, K., Koikari, S. and Nagase, Y., Flux measurement of a new beam-down solar concentrating system in Miyazaki for demonstration of thermochemical water splitting, Energy Procedia 49(2014), pp.1990-1998.

Laing, D., Steinmann, W. D., Tamme, R. and Richter, C., Solid media thermal storage for parabolic trough power plants, Solar Energy 80(2006), pp.1283-1289.

Nagase, Y., Kaneko, H., Kikunaga, T., Kawamura, R. and Tomomatsu, S., Heat flux measurement without cooling on the light condensing spot of a beam-down solar concentrator, Grand renewable energy 2014(2014).

長瀬慶紀, 友松重樹, 火花点火機関における熱流束計測の精度向上 (エンジン計測での薄膜型熱流束計の条件), 日本機械学会論文集 B 編, Vol.76, No.765(2010), pp.859-864.

長瀬慶紀, 友松重樹, 河村隆介, ビームダウン式太陽集光装置の集光部のための熱流束計測（無冷却式薄膜型熱 流束計の開発)，日本機械学会論文集 B 編，Vol.79，No.805(2013)，pp.1858-1865.

長瀬慶紀, 友松重樹, 河村隆介, 熱流束計測システム, 太陽集光シミュレータシステムおよび熱流束計測方法,特 開 2014-052221(2014).

国立天文台編, 理科年表 $\mathrm{H} 27$ 年第 88 冊(2015), p.410, 丸善出版.

独立行政法人新エネルギー・産業技術総合開発機構編, NEDO 再生可能エネルギー技術白書, 第 5 章太陽熱発電・ 
太陽熱利用 p.24, <http://www.nedo.go.jp/library/ne_hakusyo_index.html\#pdfDL>, (参照日 2016 年 8 月 8 日). 松原幸治，高効率再生可能熱発電に向けた外燃式ガスタービンシステムの研究開発，伝熱， Vol.52,No.221(2013),pp.6-12.

Michels, H. and Pitz-Paal, R., Cascaded latent heat storage for parabolic trough solar power plants, Solar Energy 81(2007), pp.829-837.

Morisson, V., Rady, M., Palomp, E. and Arquis, E., Thermal energy storage systems for electricity production using solar energy direct steam generation technology, Chemical Engineering and Processing 47(2008), pp.499-507.

Schwarzbözl, P., Buck, R., Sugarmen, C., Rinf, A., Crespo, J. M., Altwegg, P. and Enrile, J., Solar gas turbine systems: Design, cost and perspectives, Solar Energy 80(2006), pp.1231-1240.

Tomomatsu, S., Suzuki, J., Nagase, Y. and Kawamura, R., Experiment study on steam generator for beam-down solar concentrator, International Journal of Innovations in Engineering and Technology(2015), pp.37-44.

\section{References}

Abhat, A., Low temperature latent heat thermal energy storage: Heat storage materials, Solar Energy, Vol.30, No.4(1983), pp.313-332.

Hasuike, H., Yoshizawa, Y., Suzuki, A. and Tamaura, Y., Study on design of molten salt solar receivers for beam-down solar concentrator, Solar Energy 80(2006), pp.1255-1262.

JSME, JSME Data Book: Heat Transfer $5^{\text {th }}$ Edition (2009), p.162, p.287, p.296 (in Japanese).

Kodama, T., Gokon, N., Matsubara, K., Koikari, S. and Nagase, Y., Flux measurement of a new beam-down solar concentrating system in Miyazaki for demonstration of thermochemical water splitting, Energy Procedia 49(2014), pp.1990-1998.

Laing, D., Steinmann, W. D., Tamme, R. and Richter, C., Solid media thermal storage for parabolic trough power plants, Solar Energy 80(2006), pp.1283-1289.

Nagase, Y., Kaneko, H., Kikunaga, T., Kawamura, R. and Tomomatsu, S., Heat flux measurement without cooling on the light condensing spot of a beam-down solar concentrator, Grand renewable energy 2014(2014).

Nagase, Y. and Tomomatsu, S., Improvement of heat flux measurement on combustion chamber of spark ignition engine (Conditions of thin film type of heat flux sensor for heat flux measurement of engine), Transactions of the Japan Society of Mechanical Engineers, Series B, Vol.76, No.765(2010), pp.859-864 (in Japanese).

Nagase, Y., Tomomatsu, S. and Kawamura, R., Heat flux measurement for light condensing part of beam-down solar concentrator (Development of non-cooling thin-film heat flux sensor), Transactions of the Japan Society of Mechanical Engineers, Series B, Vol. 79, No.805(2013), pp.1858-1865 (in Japanese).

Nagase, Y., Tomomatsu, S. and Kawamura, R., Heat flux measurement system, solar collecting simulator system and heat flux measurement method, Japanese patent disclosure 2014-052221(2014) (in Japanese).

National Astronomical Observatory of Japan, Chronological scientific tables 2015(2015), p.410, Maruzen publishing (in Japanese).

New energy and industrial technology development organization, NEDO renewable energy technology white paper, Chapter 5 Solar thermal power generation and solar heat utilization p.24, available from $<$ http://www.nedo.go.jp/library/ne_hakusyo_index.html\#pdfDL $>$, (accessed on 8 August,2016) (in Japanese).

Matsubara, K., Research and development of external fired gas turbine system for efficient power generation from renewable heat source, Journal of the Heat Transfer Society of Japan, Vol.52, No.221(2013), pp.6-12 (in Japanese).

Michels, H. and Pitz-Paal, R., Cascaded latent heat storage for parabolic trough solar power plants, Solar Energy 81(2007), pp.829-837.

Morisson, V., Rady, M., Palomp E. and Arquis, E., Thermal energy storage systems for electricity production using solar energy direct steam generation technology, Chemical Engineering and Processing 47(2008), pp.499-507.

Schwarzbözl, P., Buck, R., Sugarmen, C., Rinf, A., Crespo, J. M., Altwegg, P. and Enrile, J., Solar gas turbine systems: Design, cost and perspectives, Solar Energy 80(2006), pp.1231-1240.

Tomomatsu, S., Suzuki, J., Nagase, Y. and Kawamura, R., Experiment study on steam generator for beam-down solar concentrator, International Journal of Innovations in Engineering and Technology (2015), pp.37-44. 